\title{
Problems in physical therapy and rehabilitation in Schwartz-Jampel syndrome: case study
}

\author{
Problemy w postępowaniu fizykalno-usprawniającym w zespole \\ Schwartza-Jampela - opis przypadku
}

\author{
Włodzisław Kuliński ${ }^{1,2}$, Mateusz Burak ${ }^{1}$ \\ ${ }^{1}$ Department of Physical Medicine, Institute of Physiotherapy, Jan Kochanowski University, Kielce, Poland \\ Head of the Department: Prof. JKU Włodzislaw Kuliński PhD \\ 2Department of Rehabilitation, Military Medical Institute, Warsaw, Poland \\ Head of the Department: Prof. Włodzislaw Kuliński PhD
}

Key words: rehabilitation, physical therapy, Schwartz-Jampel syndrome.

Słowa kluczowe: rehabilitacja, fizykoterapia, zespół Schwartza-Jampela.

\begin{abstract}
Schwartz-Jampel syndrome (SJS) is a rare genetic disorder characterised by myotonia and bone dysplasia. It is inherited as an autosomal recessive trait and caused by mutations in the gene encoding perlecan (HSPG2). Its symptoms include muscular stiffness and hypertrophy. The aim of the study was to analyse the clinical presentation as well as the physical therapy and rehabilitation in a patient with SJS. A 16-year-old patient with SJS has been followed up by the authors for the last 2 years. We assessed the physical therapy and rehabilitation conducted at home and presented the possibilities of an extended programme that can be implemented at the multi-field Division of Physical Medicine. Patients with SJS represent an extremely difficult clinical and therapeutic problem.
\end{abstract}

\section{Streszczenie}

Zespół Schwartza-Jampela (SJS) to rzadka choroba genetyczna charakteryzująca się miotonią i dysplazją kostną. Choroba dziedziczona jest autosomalnie recesywnie i spowodowana mutacjami w genie kodującym perlekan HSPG2. Wśród objawów przeważają sztywność mięśni i hipertrofia mięśniowa. Celem pracy była analiza obrazu klinicznego oraz postępowania fizykalno-usprawniającego u chorego z SJS. Chory, lat 16, z zespołem SJS był obserwowany przez autorów przez ostatnie 2 lata. W pracy oceniono postępowanie fizykalno-usprawniające prowadzone w warunkach domowych oraz przedstawiono możliwości rozszerzonego programu do realizowania w warunkach wieloprofilowego Zakładu Medycyny Fizykalnej. Przypadek zaprezentowano ze względu na to, że chorzy z SJS stanowią bardzo trudny problem kliniczny i leczniczy.

\section{Introduction}

Schwartz-Jampel syndrome (SJS) was described by Oscar Schwartz and Robert Jampel in two siblings in 1962 and by Aberfeld in 1965 [1, 2]. It is a rare genetic disorder characterised by myotonia and bone dysplasia. Its phenotype is not homogeneous as there are two types of the syndrome. They are both inherited as an autosomal recessive trait and differ in terms of symptom severity $[3,4]$. The incidence of SJS is unknown and its influence on the length of life has not been clearly determined; it can be affected by the discomfort connected with muscular stiffness and eyelid spasms. Skeletal anomalies and physical deformities may contribute to depression in the patients. Schwartz-Jampel syndrome is found both in women and men, irrespective of race. The syndrome is inherited as an autosomal recessive trait and results from mutations in the gene encoding perlecan (HSPG2) at $1 \mathrm{p} 36.1[5,6]$.

The main clinical symptoms include muscular stiffness and muscular hypertrophy. These dysmorphic features are visible as early as at birth. Muscle weakness causes motor development delay while muscle stiffness increases with age and hinders gait, mainly due to limited knee flexion. The following features are also found in the patients: narrowed palpebral fissures, blepharospasms, flattened face, short neck, kyphotic chest, and long bone abnormalities [7, 8].

\section{Case report}

A 16-year-old boy was of short stature, stocky and athletic with a short neck (height $162 \mathrm{~cm}$, weight $50 \mathrm{~kg}$ ), little facial expression, narrow palpebral fissures, periodically increased facial muscle tone, (myo- 
tonic in character), and persistent myotonic response of the orbicularis oculi and masseter muscles. His posture was poor with shoulders in significant protraction, round back and sway back, pigeon chest, and abnormal flexion in both elbows and radiocarpal joints. There was muscle weakening, especially visible within the upper limbs in the form of flexors dominating over the extensors, myotonia, and slight anterior pelvic tilt. Muscle strength was /+/3/-/4/ (upper and lower limb) on the Lovett scale. The patient had an abnormal gait pattern, a stiff and swaying gait, and a significant problem in the rolling phase and preswing. He had low tolerance for physical activity, fast fatigability, and severe blepharospasms. Deep tendon reflexes were active, equal, and identical on both sides. The patient's cardiovascular and respiratory performance was normal. We conducted additional examinations; ECG showed a regular heart rate (74/min) and ECG tracing was normal. An electromiography (EMG) revealed normal conductivity in the peripheral nerves. There were persistent myotonic responses within the orbicularis oculi, orbicularis oris, and masseter muscles.

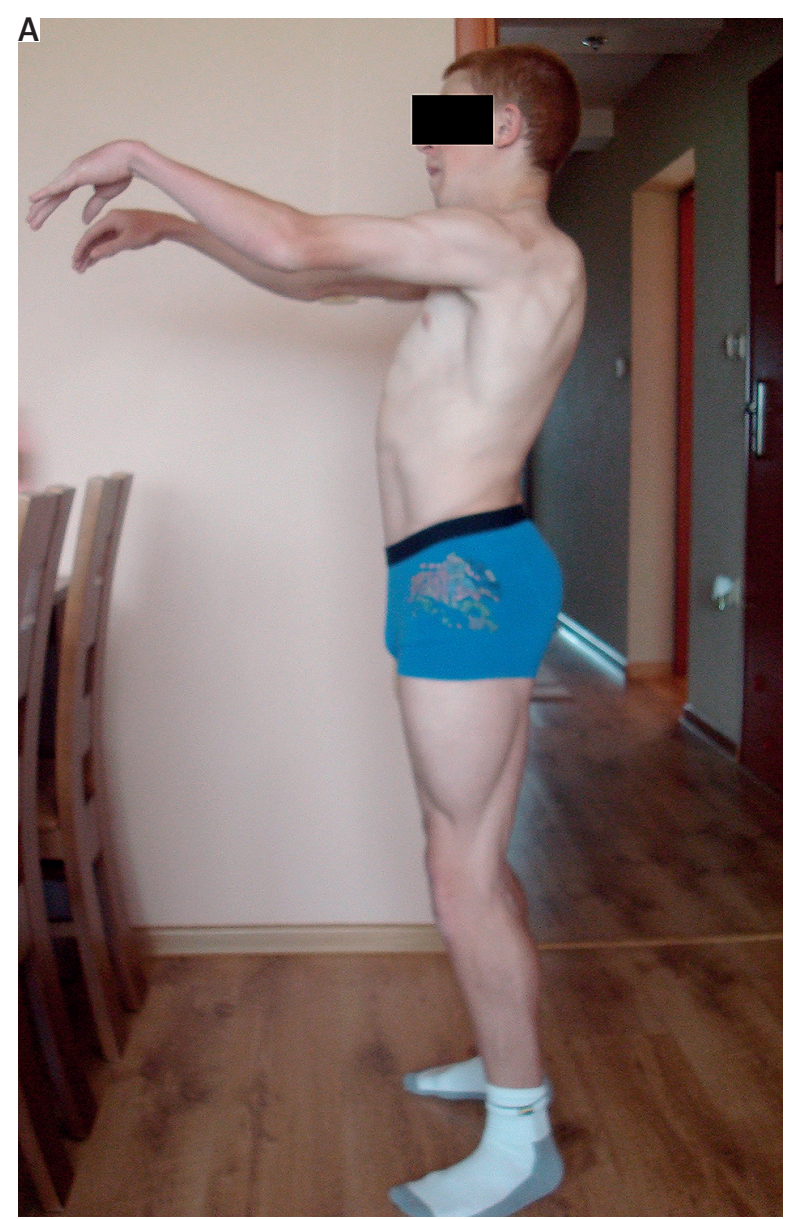

Figure 1 A-B. Patient with Schwartz-Jampel syndrome
He was born by natural birth from the third pregnancy with an Apgar score of 10 and a birth weight of $3000 \mathrm{~g}$. His older siblings, a brother and a sister, are healthy. Since birth, his body mass and height increased slowly. He often suffered from respiratory tract infections and dysphagia, vomited the gastric contents, and ate only mixed (blended) meals. Periodically, he took Amizepin (carbamazepine).

Physical therapy and rehabilitation were conducted at the patient's house in a rural area (a place located more than a dozen kilometres from the nearest small village). Consequently, there were very limited possibilities of therapy. The program includes: irradiation with a Sollux lamp, hydromassage of the whole body, upper limb massage, prorioceptive neuromuscular facilitation (PNF) exercises, functional application of the upper limbs, manual exercises with a board, respiratory and phonatory exercises, and the use of orthoses maintaining physiological position of the upper limbs in the radiocarpal joints.

After 2 years of rehabilitation we achieved: improved gait pattern (improved foot rolling); improved manipulative function of the hand (better use of

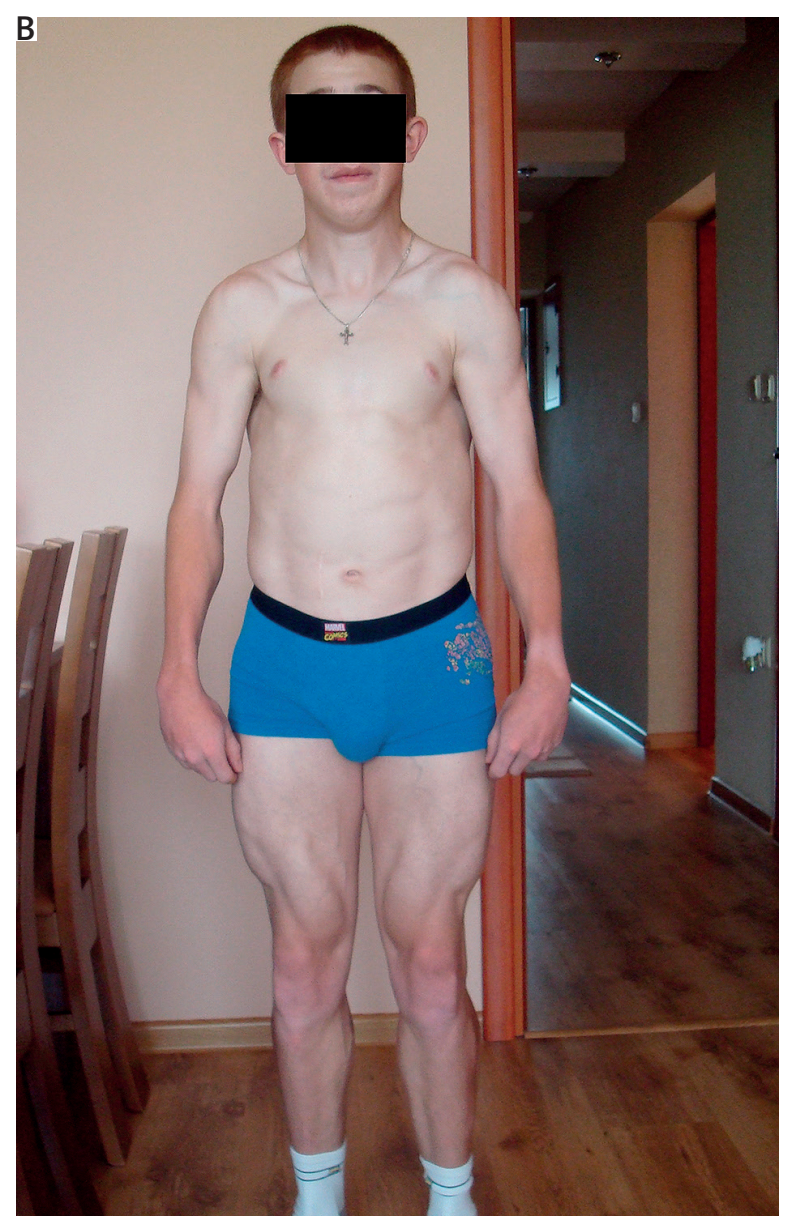


cutlery, better pencil grip); more efficient changes of position (sitting to standing, supine to prone); partial decrease in spasticity; improvement with respect to self-care (use of the toilet, more efficient getting up after fall); improved central and peripheral stability. Figures $1 \mathrm{~A}$ and B present the boy's posture.

\section{Discussion}

Schwartz-Jampel syndrome is a rare genetic disorder characterised by myotonia and bone dysplasia. It is caused by mutations in the gene encoding perlecan. Perlecan is a heparan sulphate proteoglycan present in the basement membrane and in the extracellular matrix adjacent to cells. It is synthesised both by the vascular endothelium and smooth muscle cells and is found in the extracellular matrix. Perlecan is present early in utero, interacting with laminin and entactin to create basement membrane architecture. It also facilitates the regulation of cell proliferation and migration and helps maintain the barrier function of the endothelium. Moreover, it plays an important role in angiogenic processes. It is a strong inhibitor of smooth muscle cell proliferation and thus participates in maintaining vascular homeostasis. Perlecan promotes the activity of fibroblast growth factor 2 (FGF2) and, consequently, stimulates endothelial growth and regeneration. As a non-collagenous protein, perlecan forms the bone structure and influences cartilage compressibility.

Schwartz-Jampel syndrome may be progressive. The etiopathogenesis of the syndrome has been studied since the description of the first 7 cases observed in Africa.

The patient followed up by the authors was diagnosed and treated at numerous paediatric departments since birth due to short stature, underweight, dysmorphia, dysphagia, and psychomotor development delay.

At first, differential diagnosis took into consideration various disorders. When the patient was 3 years old, the diagnosis was oriented after a cytogenetic examination. In addition, the older siblings were confirmed to have a pathogenic mutation in the gene encoding perlecan (HSPG2). Both siblings are carriers of this gene. The physical therapy and rehabilitation conducted at the patient's house are difficult due to persistent muscle stiffness that limits the motion in the joints, especially in the knee, wrist, and upper limbs. This hinders changing positions and performing exercises. There is a tendency towards increased muscular stiffness on cold rainy days and during winter. In summer, the stiffness is reduced. Fast fatigability is connected with excessive sweating. After several hours of normal activity the boy is very tired, and after coming home from school he is often unable to undress himself, open the door, or perform basic household chores on his own. The programme of rehabilitation conducted at home is adjusted to the current physical condition of the patient and includes periodical breaks so as not to exhaust him.

The intellectual development of patients with SJS is usually normal, but in approximately $20 \%$ of cases there is mild intellectual disability. The disturbances in the intellectual development may be secondary and result from abnormal development of speech and motor problems caused by osteoarticular defects. Therapeutic management of the patients requires the efforts of numerous specialists. In the case of our patient, the rehabilitation takes place at home in a rural area, far from a multi-field facility where the patient could undergo an extended rehabilitation programme. The following procedures should be implemented: thermotherapy (paraffin compresses), selected electrotherapeutic procedures, variable lowfrequency magnetic fields, laser therapy, underwater massage, whirlpool massage, and carbonic acid baths $[9,10]$.

The kinesiotherapy programme should be extended to include antigravity exercises, balance exercises, and occupational therapy. Due to very limited possibilities of rehabilitation at the place of residence, the patient should be systematically (1-2 times a year) referred for health resort hospital treatment to undergo a comprehensive programme of physical therapy and rehabilitation.

The patient's family should receive genetic counselling aimed at estimating the risk of future children inheriting SJS and information about possible prenatal testing.

\section{Conclusions}

Schwartz-Jampel syndrome is a difficult diagnostic and therapeutic problem. Physical therapy and rehabilitation constitute the basis for the treatment of this disorder.

\section{References}

1. Schwartz O, Jampel RS. Congenital blepharophimosis associated with a unique generalized myopathy. Arch Ophthal 1962; 68: 52-7.

2. Aberfeld DC, Hinterbuchner L, Schneider M. Myotonia, dwarfism, diffuse bone disease and unusual ocular and facial abnormalities (a new syndrome). Brain 1965; 88: 313-22.

3. Viljoen D, Beighton P. Schwartz-Jampel syndrome (chondrodystrophic myotonia). J Med Genet 1992; 29: 58-62.

4. Ho NC, Sandusky S, Madike V, et al. Clinico-pathogenetic findings and management of chondrodystrophic myotonia (Schwartz-Jampel syndrome): a case report. BMC Neurol 2003; 3: 3.

5. Arikawa-Hirasawa E, Le AH, Nishino I, et al. Structural and functional mutations of the perlecan gene cause SchwartzJampel syndrome, with miotonic myopathy and chondrodysplasia. Am J Hum Genet 2002; 70: 1368-75. 
6. Farrell SA, Davidson RG, Thorp P. Neonatal manifestations of Schwartz Jampel syndrome. Am J Med Genet 1987; 27: 799-805.

7. Giedion A, Boltshauser E, Briner J, et al. Heterogeneity in Schwartz-Jampel chondrodystrophic myotonia. Eur J Pediatr 1997; 156: 214-23.

8. Sguires LA, Pranglej J. Neonatal diagnosis of Schwartz Jampel syndrome with dramatic response to carbamazepine. Ped Neurol 1996; 15: 172-4.

9. Kuliński W. Fizykoterapia. In: Fizjoterapia w pediatrii. Kuliński W (ed.) Wydawnictwo Lekarskie PZWL, Warsaw 2012; 315-50.

10. Kuliński W. Balneoterapia. In: Fizjoterapia w pediatrii. Kuliński W (ed.) Wydawnictwo Lekarskie PZWL, Warsaw 2012; 350-9.

\section{Address for correspondence:}

Prof. JKU Włodzisław Kuliński MD, PhD

Department of Physical Medicine

Institute of Physiotherapy

Jan Kochanowski University

al. IX Wieków Kielc 19, 25-317 Kielce, Poland

Phone: +48 226383164

E-mail: wkulinski52@hotmail.com 